\title{
Improvement in the Anticancer Activity of 6-Mercaptopurine via Combination with Bismuth(III)
}

\author{
Yang Yang, ${ }^{a, \#}$ Shuang Zhou, ${ }^{b, \#}$ Ruizhuo Ouyang, ${ }^{* a}$ Yaoqin Yang, ${ }^{b}$ Huihong Tao, ${ }^{b}$ Kai Feng, ${ }^{a}$ \\ Xiaoshen Zhang, ${ }^{b}$ Fei Xiong, ${ }^{a}$ Ning Guo, ${ }^{a}$ Tianyu Zong, ${ }^{a}$ Penghui Cao, ${ }^{a}$ Yuhao Li, ${ }^{a}$ and \\ Yuqing $\mathrm{Miao}^{*, a}$ \\ ${ }^{a}$ University of Shanghai for Science and Technology; Shanghai 200093, China: and ${ }^{b}$ Cancer Institute, Tongji \\ University School of Medicine; Shanghai 200092, China. \\ Received November 27, 2015; accepted August 13, 2016
}

\begin{abstract}
6-Mercaptopurine (6-MP) is a clinically important antitumor drug and its commercially available form is provided as monohydrate, belonging to biopharmaceuticals classification system (BCS) class II category. The combination of bismuth(III) (Bi(III)) with 6-MP was proved to significantly improve the anticancer activity of 6-MP, leading to the discovery of a new amorphous complex $\left(\left[\mathrm{Bi}(\mathrm{MP})_{3}\left(\mathrm{NO}_{3}\right)_{2}\right] \mathrm{NO}_{3}\right)$. The prepared $\left[\mathrm{Bi}(\mathrm{MP})_{3}\left(\mathrm{NO}_{3}\right)_{2}\right] \mathrm{NO}_{3}$ was characterized by the matrix assisted laser desorption-ionization time-of-flight (MALDI-TOF)-MS, etc. Noticeably, according to the in vitro evaluations of cytotoxicity, cellular apoptotic, colony formation as well as cell migration, the anticancer activity of amorphous $\left[\mathrm{Bi}(\mathrm{MP})_{3}\left(\mathrm{NO}_{3}\right)_{2}\right] \mathrm{NO}_{3}$ was found to be of high therapeutic effect over 6-MP.
\end{abstract}

Key words 6-mercaptopurine; bismuth; $\left[\mathrm{Bi}(\mathrm{MP})_{3}\left(\mathrm{NO}_{3}\right)_{2}\right] \mathrm{NO}_{3}$; anticancer; A549 cancer cell

Currently, in many cases, promising drug candidates have been eliminated from late-stage cancer development due to their poor bioavailability/solubility. ${ }^{1)}$ In order to overcome the solubility limitations and alter the physicochemical, biopharmaceutical, and/or pharmacotechnical characters of a given drug, pharmaceutical scientists generally explore different solid-state forms of a certain active pharmaceutical ingredient (API). Solid drugs could exist in various forms such as amorphous and different polymorphs, solvates, and salts. Most recently, by comparison with the crystalline state of APIs, the amorphous state ones have been found to have higher dissolution rates and better solubility due to the higher degree of free energy. However, the stability usually decreases with increasing free energy. Amorphous solids, therefore, tend to be thermodynamically unstable compared with their crystalline equivalents. ${ }^{2}$

6-Mercaptopurine (6-MP) is one of important antimetabolite and antineoplastic APIs in the clinical treatment of human acute lymphoblastic leukemia, systemic lupus erythematosus, rheumatoid arthritis and inflammatory bowel disease, ${ }^{3,4)}$ but has not been applied in lung cancer treatment yet so far. Its commercially available form is provided as monohydrate. 6-MP belongs to biopharmaceuticals classification system (BCS) class II category with low oral bioavailability (about $16 \%$ ) due to its poor water solubility $(0.135 \mathrm{mg} / \mathrm{mL}),{ }^{5)}$ which to some extent limits the biomedical application of 6-MP. So efforts should be made to improve the bioavailability/solubility of 6-MP and explore its anticancer effect on certain cancer cell lines, like lung cancer.

Bismuth is well known for its extra-low toxicity and environmentally friendly ${ }^{6)}$ and therefore has been widely selected to replace the traditional triple therapy with bismuth-containing quadruple rescue therapy for the treatment of gastropathy infected by Helicobacter pylori. ${ }^{7-10)}$ Such remarkably low

\footnotetext{
\#These authors contributed equally to this work.

toxicity of bismuth compounds has been attributed to their insolubility in neutral aqueous solutions like biological fluids. The element arsenic in the same main group as bismuth, is known for its anticancer effects in tumor cells through binding to thiols in cysteine residues. ${ }^{11)}$ Recently, many proteinlabeling agents have been already explored based on the high affinity of trivalent arsenicals with vicinal dithiols. ${ }^{12-15)}$ Therefore, bismuth(III) (Bi(III)), particularly the organometallic Bi(III) complexes, was assumed to have the same quality of anticancer in this work. In addition, the bioactivity of Bi(III) containing complexes like treatment of a variety of gastrointestinal disorders, antitumor, antimicrobial, and antibacterial activities have been reported. ${ }^{7,9,10,16-19)}$ So, the solubility and bioavailability of 6-MP was expected to be improved by coordination between $\mathrm{Bi}(\mathrm{III})$ and 6-MP, forming an amorphous complex.

Herein, we showed the synthesis and characteristic of a new $\mathrm{Bi}(\mathrm{III})$-containing complex derived from 6-MP (described as $\left.\left[\mathrm{Bi}(\mathrm{MP})_{3}\left(\mathrm{NO}_{3}\right)_{2}\right] \mathrm{NO}_{3}\right)$ and well explored its in vitro anticancer effects on human lung cancer cells of A549 and H460 by evaluating the biological activities including cytotoxicity, colony formation rate, cell migration rate as well as cellular apoptosis. The obtained results demonstrate that the combination of $\mathrm{Bi}$ (III) with 6-MP endowed the newly developed amorphous $\left[\mathrm{Bi}(\mathrm{MP})_{3}\left(\mathrm{NO}_{3}\right)_{2}\right] \mathrm{NO}_{3}$ with excellent anticancer activity against lung cancer cells and the solubility and bioavailability of the obtained $\left[\mathrm{Bi}(\mathrm{MP})_{3}\left(\mathrm{NO}_{3}\right)_{2}\right] \mathrm{NO}_{3}$ were dramatically improved, compared with that of $6-\mathrm{MP}$. Therefore, the prepared $\left[\mathrm{Bi}(\mathrm{MP})_{3}\left(\mathrm{NO}_{3}\right)_{2}\right] \mathrm{NO}_{3}$ was considered to be potentially used as highly efficacious anticancer agent for the treatment of cancer.

\section{Results and Discussion}

6-MP was first dissolved in ethanol with $\mathrm{Bi}\left(\mathrm{NO}_{3}\right)_{3}$ solution added in afterwards. Once $\mathrm{Bi}\left(\mathrm{NO}_{3}\right)_{3}$ solution was dropped in, the $\mathrm{Bi}(\mathrm{III})$ and thiol easily formed metalsulfur bond, leading to the formation of yellow solid, 
$\left[\mathrm{Bi}(\mathrm{MP})_{3}\left(\mathrm{NO}_{3}\right)_{2}\right] \mathrm{NO}_{3}$, as shown in Chart 1 . The obtained $\left[\mathrm{Bi}(\mathrm{MP})_{3}\left(\mathrm{NO}_{3}\right)_{2}\right] \mathrm{NO}_{3}$ was finally washed with acetone. The solubility of $\left[\mathrm{Bi}(\mathrm{MP})_{3}\left(\mathrm{NO}_{3}\right)_{2}\right] \mathrm{NO}_{3}$ was measured to be $1.2 \mathrm{mg} /$ $\mathrm{mL}$, about 8.6 times higher than that of $6-\mathrm{MP}(\mathrm{ca} .0 .14 \mathrm{mg}$ / $\mathrm{mL}$ ), as shown in Fig. 1. Additionally, solutions of 6-MP and $\left[\mathrm{Bi}(\mathrm{MP})_{3}\left(\mathrm{NO}_{3}\right)_{2}\right] \mathrm{NO}_{3}$ were individually prepared at concentrations of $0.1,0.5$ and $1.0 \mathrm{mg} / \mathrm{mL}$. Clearly, multi-phase solutions were achieved at concentrations of 0.1 and $0.5 \mathrm{mg} / \mathrm{mL}$ for 6-MP (inset A), while $\left[\mathrm{Bi}(\mathrm{MP})_{3}\left(\mathrm{NO}_{3}\right)_{2}\right] \mathrm{NO}_{3}$ solutions at same concentrations were quite transparent (inset $\mathrm{B}$ ), verifying the improvement in solubility of $\left[\mathrm{Bi}(\mathrm{MP})_{3}\left(\mathrm{NO}_{3}\right)_{2}\right] \mathrm{NO}_{3}$ over 6-MP. The result means the obtained compound could be dissolved much easier in gut and its bioavailability was thus improved. Moreover, the solubility of $\left[\mathrm{Bi}(\mathrm{MP})_{3}\left(\mathrm{NO}_{3}\right)_{2}\right] \mathrm{NO}_{3}$ was found better than that of the previously reported $\mathrm{Zn}$ containing complex as well, ${ }^{20)}$ demonstrating a better bioavailability.

The energy dispersive spectroscopy (EDS) analysis was accompanied to investigate the molar ratio of $\mathrm{Bi}(\mathrm{III})$ to $6-\mathrm{MP}$,

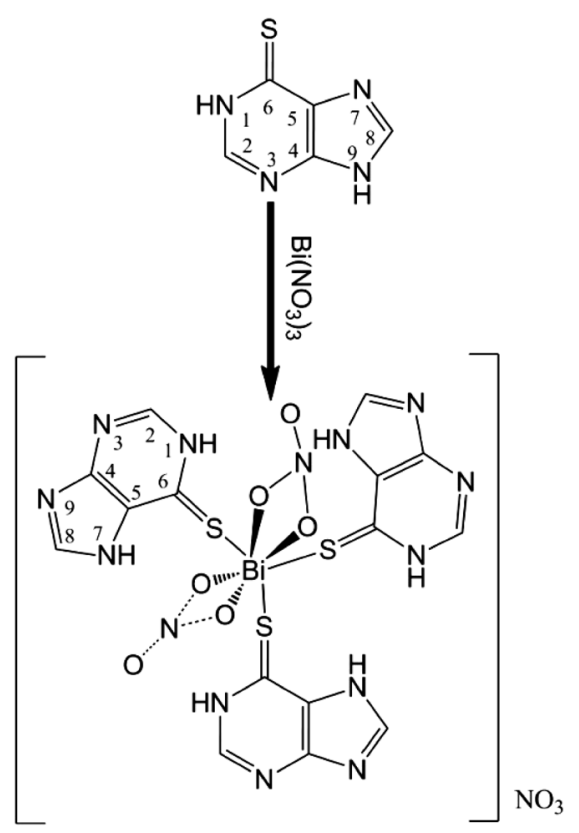

Chart 1. Synthesis Route of $\left[\mathrm{Bi}(\mathrm{MP})_{3}\left(\mathrm{NO}_{3}\right)_{2}\right] \mathrm{NO}_{3}$

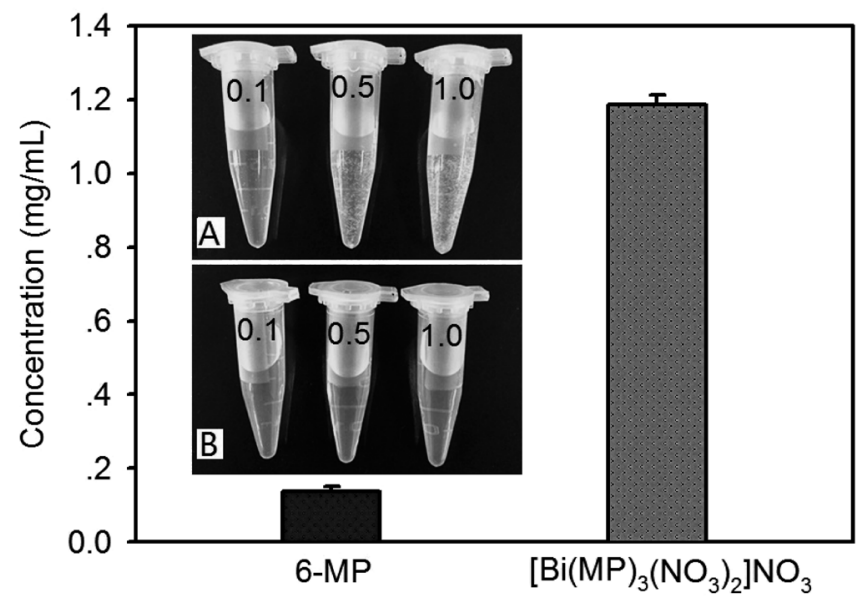

Fig. 1. Solubility of 6-MP and $\left[\mathrm{Bi}(\mathrm{MP})_{3}\left(\mathrm{NO}_{3}\right)_{2}\right] \mathrm{NO}_{3}$ (Inset: Photos of A) 6-MP and $\mathrm{B})\left[\mathrm{Bi}(\mathrm{MP})_{3}\left(\mathrm{NO}_{3}\right)_{2}\right] \mathrm{NO}_{3}$ Solutions at Concentrations of 0.1, 0.5 and $1.0 \mathrm{mg} / \mathrm{mL}$ ) attached to scanning electron microscope (SEM) measurements. The result in Fig. 2 showed a molar ratio of $1: 3$ for $\mathrm{Bi}(\mathrm{III})$ to $6-\mathrm{MP}$ in $\left[\mathrm{Bi}(\mathrm{MP})_{3}\left(\mathrm{NO}_{3}\right)_{2}\right] \mathrm{NO}_{3}$ complex structure. Since proton of $\mathrm{C}-\mathrm{SH}$ in 6-MP was easily rearranged in acidic media by converting $-\mathrm{SH}$ to $\mathrm{C}=\mathrm{S}$, three proton rearranged 6-MP coordinated with one $\mathrm{Bi}(\mathrm{III})$ through $\mathrm{Bi}-\mathrm{S}$ bond. The matrix assisted laser desorption-ionization time-of-flight (MALDI-TOF)-MS was recorded in the positive mode to identify the complex, where a peak at $\mathrm{m} / \mathrm{z} 790.04$ indicated the presence of complex as $[\mathrm{M}]^{+}$(Fig. 3). It means the analyzed molecular weight (MW) of the complex was as predicted. Moreover, the other characterizations of $\left[\mathrm{Bi}(\mathrm{MP})_{3}\left(\mathrm{NO}_{3}\right)_{2}\right] \mathrm{NO}_{3}$ structure was accomplished by NMR, Fourier transform (FT)IR, simultaneous thermal analyses (STA), etc. (see Supplementary materials).

The inhibition abilities of both the obtained compound $\left[\mathrm{Bi}(\mathrm{MP})_{3}\left(\mathrm{NO}_{3}\right)_{2}\right] \mathrm{NO}_{3}$ and the starting compounds $\mathrm{Bi}\left(\mathrm{NO}_{3}\right)_{3}$ and 6-MP against the lung cancer cells of A549 and H460 were investigated individually so as to evaluate the anticancer activity of $\left[\mathrm{Bi}(\mathrm{MP})_{3}\left(\mathrm{NO}_{3}\right)_{2}\right] \mathrm{NO}_{3}$. Figure 4 shows that 6-MP alone was inactive as $\mathrm{IC}_{50}$ was over $150 \mu \mathrm{M}$, about 2 fold higher than that of $\mathrm{Bi}\left(\mathrm{NO}_{3}\right)_{3}$ (around $70 \mu \mathrm{M}$ ), while $\left[\mathrm{Bi}(\mathrm{MP})_{3}\left(\mathrm{NO}_{3}\right)_{2}\right] \mathrm{NO}_{3}$ exhibited excellent anticancer activity against either A549 or $\mathrm{H} 460$ cancer cell with $\mathrm{IC}_{50}$ ranging from 7 to $11 \mu \mathrm{M}$, lower than that of $\mathrm{K}(\mathrm{AuMP})_{2}{ }^{21)}$ In order to examine the stability of and cytotoxicity of $\left[\mathrm{Bi}(\mathrm{MP})_{3}\left(\mathrm{NO}_{3}\right)_{2}\right] \mathrm{NO}_{3}$ itself before being hydrolyzed to 6-MP, $\mathrm{IC}_{50}$ assay of $\mathrm{Bi}(\mathrm{III})+6-\mathrm{MP}$ mixture

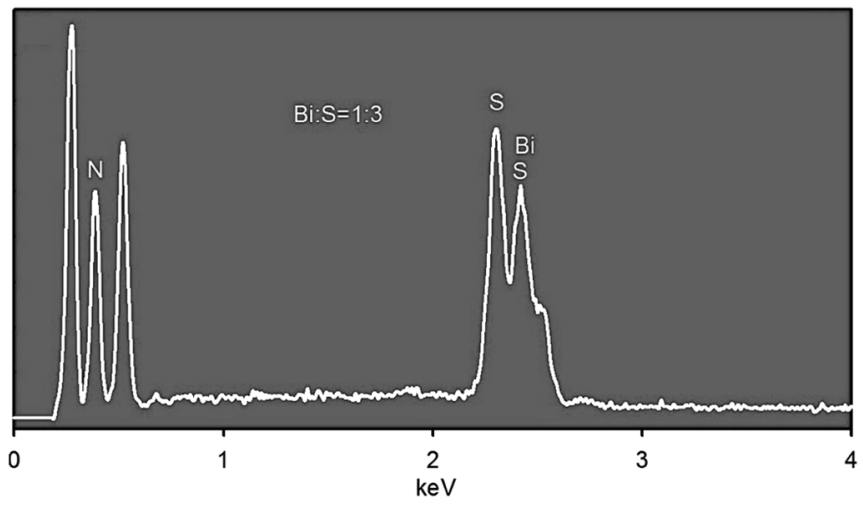

Fig. 2. EDS Measurement of $\left[\mathrm{Bi}(\mathrm{MP})_{3}\left(\mathrm{NO}_{3}\right)_{2}\right] \mathrm{NO}_{3}$ Complex

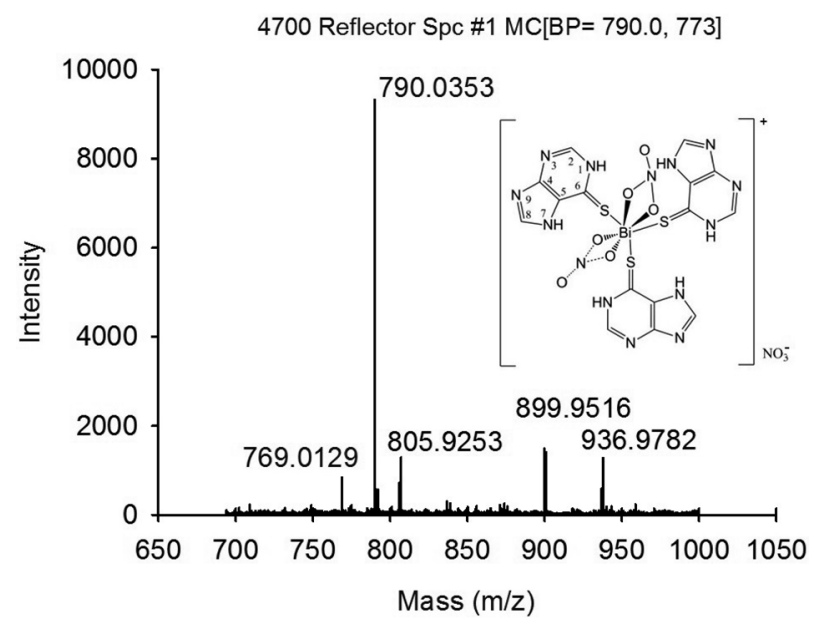

Fig. 3. MALDI-TOF Mass Spectrum of $\left[\mathrm{Bi}(\mathrm{MP})_{3}\left(\mathrm{NO}_{3}\right)_{2}\right] \mathrm{NO}_{3}$ Complex 
(molar ratio of $\mathrm{Bi}(\mathrm{III})$ to $6-\mathrm{MP}=1: 3$ ) was performed. $\mathrm{The} \mathrm{IC}_{50}$ values of $\mathrm{Bi}(\mathrm{III})+6-\mathrm{MP}$ (counted based on $\mathrm{Bi}(\mathrm{III})$ content) were 104 and $129 \mu \mathrm{m}$ for A549 and $\mathrm{H} 460$, respectively, which was significantly higher than that of $\left[\mathrm{Bi}(\mathrm{MP})_{3}\left(\mathrm{NO}_{3}\right)_{2}\right] \mathrm{NO}_{3}$ (ranging from 7 to $11 \mu \mathrm{M}$ ). The result demonstrated that the obtained $\left[\mathrm{Bi}(\mathrm{MP})_{3}\left(\mathrm{NO}_{3}\right)_{2}\right] \mathrm{NO}_{3}$ had good stability and the coordination of $\mathrm{Bi}(\mathrm{III})$ with 6-MP endowed $\left[\mathrm{Bi}(\mathrm{MP})_{3}\left(\mathrm{NO}_{3}\right)_{2}\right] \mathrm{NO}_{3}$ with excellent anticancer activity. The possible reason was because $\left[\mathrm{Bi}(\mathrm{MP})_{3}\left(\mathrm{NO}_{3}\right)_{2}\right] \mathrm{NO}_{3}$ could more easily enter cell owing to the better solubility. Therefore, the coordination of $\mathrm{Bi}(\mathrm{III})$ with 6-MP exerted pronounced effect to the anti-

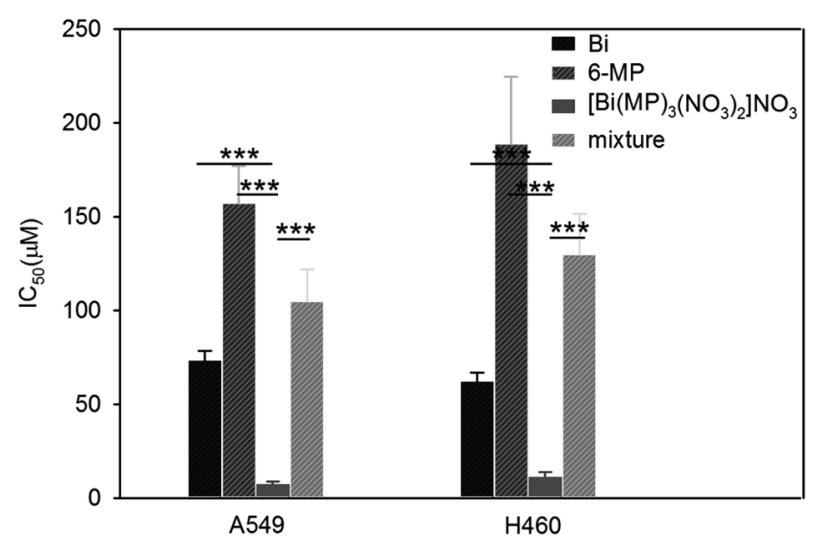

Fig. 4. $\mathrm{IC}_{50}$ of $\mathrm{A} 549$ and $\mathrm{H} 460$ Cell Lines with $\left[\mathrm{Bi}(\mathrm{MP})_{3}\left(\mathrm{NO}_{3}\right)_{2}\right] \mathrm{NO}_{3}$ Obtained via the MTT Assay and Shown as the Mean \pm S.D. of Five Independent Experiments

Mixture: $\mathrm{Bi}(\mathrm{III})+6-\mathrm{MP}$, molar ratio=1:3.
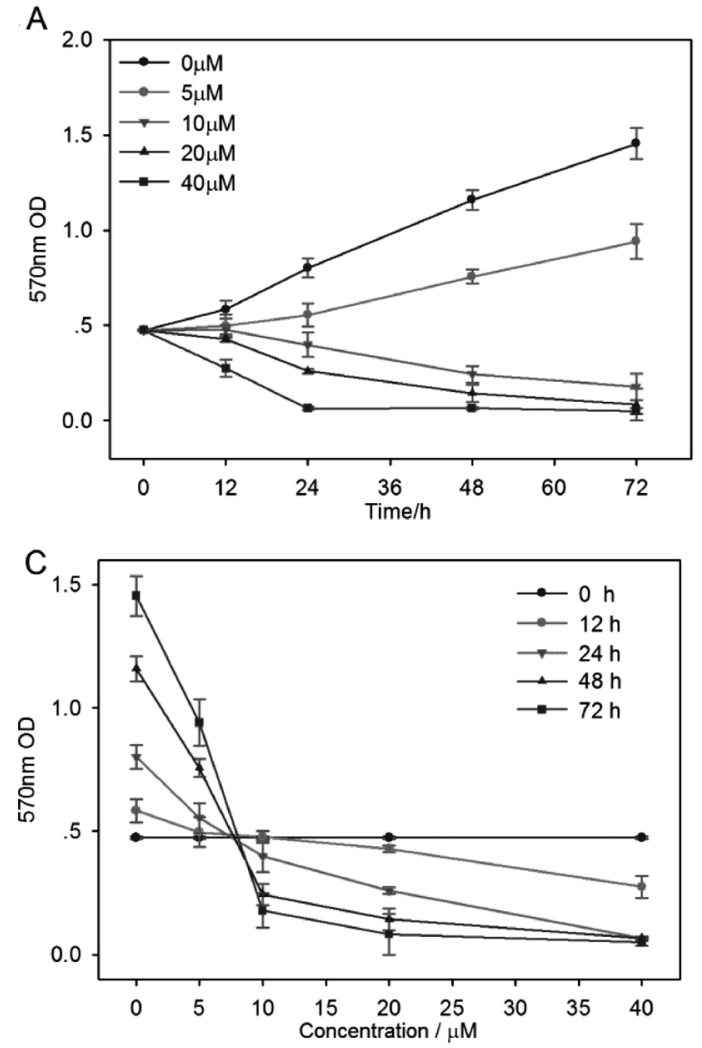

cancer capacity of $\left[\mathrm{Bi}(\mathrm{MP})_{3}\left(\mathrm{NO}_{3}\right)_{2}\right] \mathrm{NO}_{3}$ against cells A549 and $\mathrm{H} 460$, reflecting on lowest $\mathrm{IC}_{50}$ of $\left[\mathrm{Bi}(\mathrm{MP})_{3}\left(\mathrm{NO}_{3}\right)_{2}\right] \mathrm{NO}_{3}$ among three compounds. Both time and dose dependence of $\left[\mathrm{Bi}(\mathrm{MP})_{3}\left(\mathrm{NO}_{3}\right)_{2}\right] \mathrm{NO}_{3}$ on the change in inhibition rate of cancer cell with time was tested as well. As shown in Fig. 5, both dose and time dependences of $\left[\mathrm{Bi}(\mathrm{MP})_{3}\left(\mathrm{NO}_{3}\right)_{2}\right] \mathrm{NO}_{3}$ were observed for the inhibition against A549 and $\mathrm{H} 460$ cells. With more $\left[\mathrm{Bi}(\mathrm{MP})_{3}\left(\mathrm{NO}_{3}\right)_{2}\right] \mathrm{NO}_{3}$ used, obvious inhibition was found at the very first beginning of $\left[\mathrm{Bi}(\mathrm{MP})_{3}\left(\mathrm{NO}_{3}\right)_{2}\right] \mathrm{NO}_{3}$ treatment (Figs. 5A, B). However, the growth of cancer cells A549 and H460 was not efficiently inhibited after being treated over $24 \mathrm{~h}$ when the concentration of $\left[\mathrm{Bi}(\mathrm{MP})_{3}\left(\mathrm{NO}_{3}\right)_{2}\right] \mathrm{NO}_{3}$ was less than $10 \mu \mathrm{m}$. The stable and excellent inhibition rate of $\left[\mathrm{Bi}(\mathrm{MP})_{3}\left(\mathrm{NO}_{3}\right)_{2}\right] \mathrm{NO}_{3}$ against two cancer cells was achieved at the concentration higher than $10 \mu \mathrm{m}$, but bio-toxicity would be inevitably avoided when the concentration is too high. Therefore, $10 \mu \mathrm{M}$ of $\left[\mathrm{Bi}(\mathrm{MP})_{3}\left(\mathrm{NO}_{3}\right)_{2}\right] \mathrm{NO}_{3}$ was used as the optimum dosage for the lung cancer cells treatment.

Colony formation assay is an effective method to determine the proliferation capacity of single cell. In vitro single cell proliferation over 6 generations forms clone, and each clone contains at least 50 cells. The cell proliferation capacity of the living environment can be evaluated through colony formation assay. The smaller the colony formation rate is, the stronger the drugs prevent the cell proliferation. As aforementioned in the in vitro cytotoxicity assay, $10 \mu \mathrm{M}\left[\mathrm{Bi}(\mathrm{MP})_{3}\left(\mathrm{NO}_{3}\right)_{2}\right] \mathrm{NO}_{3}$ exhibited the preferable inhibition rate against cancer cells A549 and H460, and thus was used throughout the whole colony formation assay with $\mathrm{Bi}\left(\mathrm{NO}_{3}\right)_{3}$ and 6-MP at the same concentration for comparison. As seen in Figs. 6A and B,
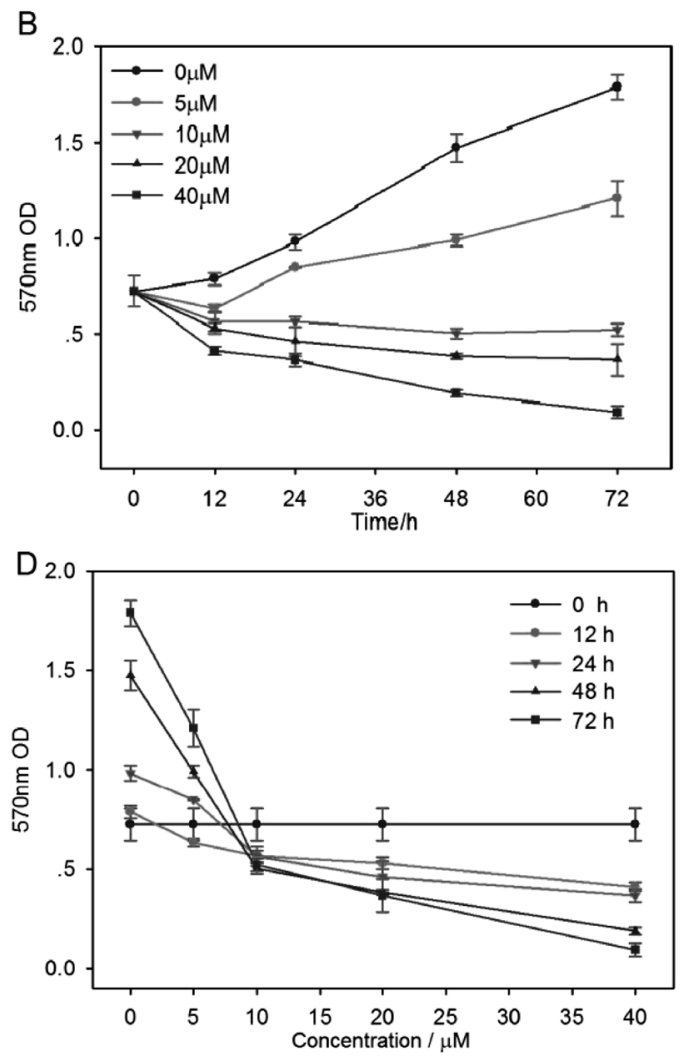

Fig. 5. Time (A, B) and Dose (C, D) Dependent Drug Efficacy Studies of $\left[\mathrm{Bi}(\mathrm{MP})_{3}\left(\mathrm{NO}_{3}\right)_{2}\right] \mathrm{NO}_{3}$ on Lung Cancer Cell Lines of (A, C) A549 and (B, D) $\mathrm{H} 460$ 
A
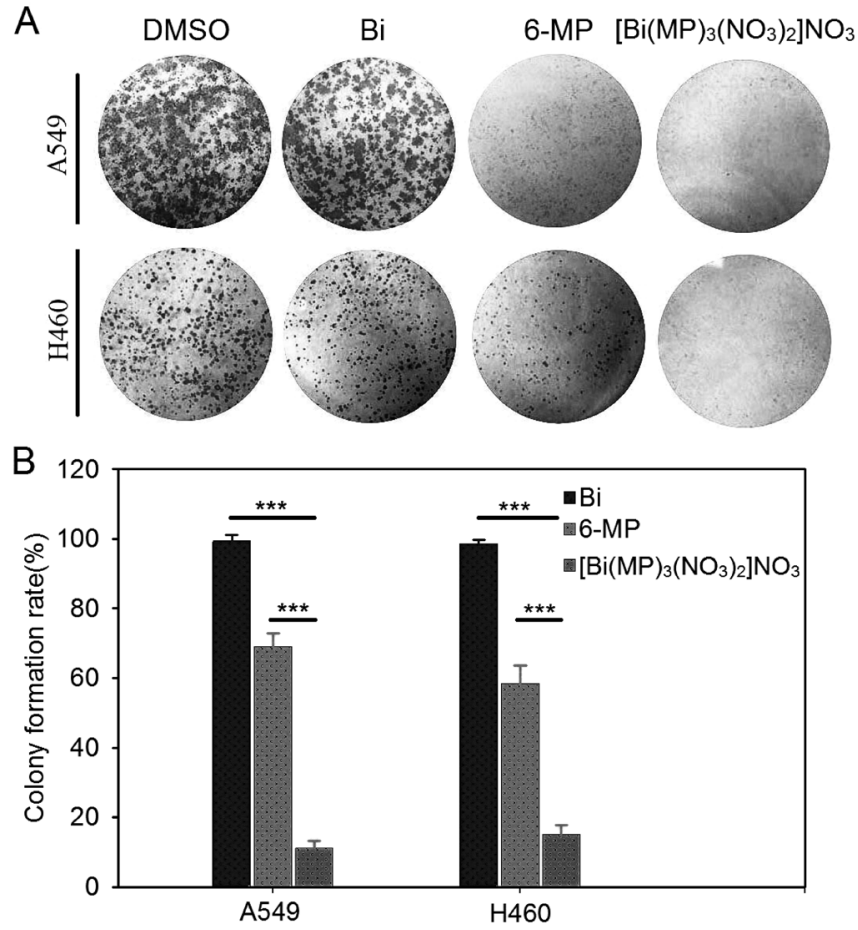

Fig. 6. The Effect of $\left[\mathrm{Bi}(\mathrm{MP})_{3}\left(\mathrm{NO}_{3}\right)_{2}\right] \mathrm{NO}_{3}$ on $\mathrm{A} 549$ and $\mathrm{H} 460$ Cell Single Cell Proliferation Shown by Colony Formation Assay

Data were shown as the mean \pm S.D. of five independent experiments. compared with control, colony formation rate higher than $50 \%$ was observed for both A549 and H460 after being treated with 6-MP. $\mathrm{Bi}\left(\mathrm{NO}_{3}\right)_{3}$ showed a very low inhibition rate against colony formation as the colony formation rate was very close to $100 \%$, while the colony formation (less than $15 \%$ ) of both cancer cells was remarkably inhibited once $10 \mu \mathrm{M} \quad\left[\mathrm{Bi}(\mathrm{MP})_{3}\left(\mathrm{NO}_{3}\right)_{2}\right] \mathrm{NO}_{3}$ was used for treatment. These results verified that the prepared $\left[\mathrm{Bi}(\mathrm{MP})_{3}\left(\mathrm{NO}_{3}\right)_{2}\right] \mathrm{NO}_{3}$ owned excellent anti-cell-proliferation activity over either $\mathrm{Bi}\left(\mathrm{NO}_{3}\right)_{3}$ or 6-MP toward lung cancer cells. The good solubility and bioavailability of $\left[\mathrm{Bi}(\mathrm{MP})_{3}\left(\mathrm{NO}_{3}\right)_{2}\right] \mathrm{NO}_{3}$ was considered to make contributions to such high anti-cell-proliferation activity.

The cell migration ability can be simply evaluated via cell scratch method. In this method, the cells were incubated with drugs right before the scratch experiments started. It would be determined whether the cell migration occurs by observing if the surrounding cells grow and move forward to the central scratch area. As compared in Figs. 7A and B, the cells of A549 and H460 clearly migrated to the scratch area with treatment time getting longer in dimethyl sulfoxide (DMSO) and $\mathrm{Bi}\left(\mathrm{NO}_{3}\right)_{3}$ and 6-MP treated experiment groups with the cell migration rate still maintaining over $70 \%$ for $\mathrm{H} 549$ and $50 \%$ for $\mathrm{H} 460$ in each group after being treated over $24 \mathrm{~h}$ (Figs. 7C, D). However, after the $24 \mathrm{~h}$ treatment with $\left[\mathrm{Bi}(\mathrm{MP})_{3}\left(\mathrm{NO}_{3}\right)_{2}\right] \mathrm{NO}_{3}$, no obvious cell migration to the scratch area was found for either A549 or H460. These results revealed that the combination of $\mathrm{Bi}(\mathrm{III})$ with 6-MP endowed $\left[\mathrm{Bi}(\mathrm{MP})_{3}\left(\mathrm{NO}_{3}\right)_{2}\right] \mathrm{NO}_{3}$ pretty high antimigration activity against lung cancer cells A549 or H460,
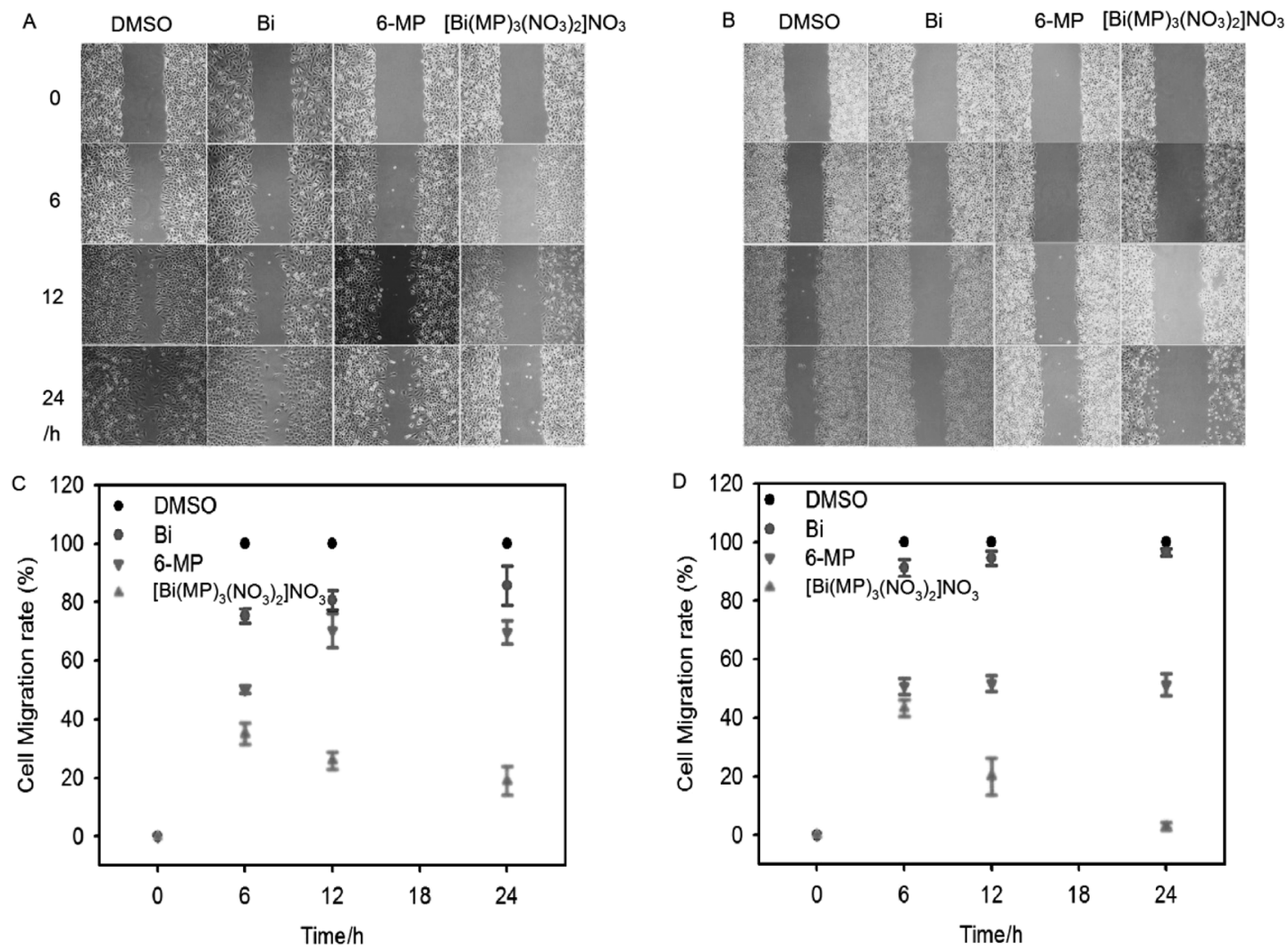

Fig. 7. The Effects of $\left[\mathrm{Bi}(\mathrm{MP})_{3}\left(\mathrm{NO}_{3}\right)_{2}\right] \mathrm{NO}_{3}$ on A) A549 and B) $\mathrm{H} 460$ Cell Motility Conducted with Wound Healing Assay; The Change in Migration Rate of $\left[\mathrm{Bi}(\mathrm{MP})_{3}\left(\mathrm{NO}_{3}\right)_{2}\right] \mathrm{NO}_{3}$ with Time for C) A549 and D) H460 Cell Lines, Using Contorl, $\mathrm{Bi}\left(\mathrm{NO}_{3}\right)_{3}$ and 6-MP as Comparision

Data were shown as the mean \pm S.D. of five independent experiments. 

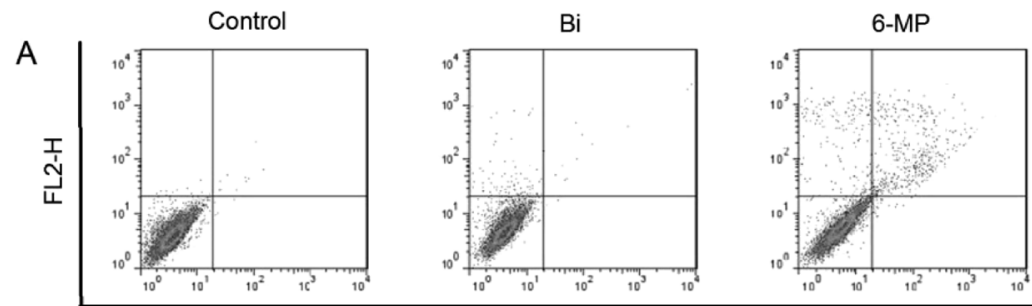

$\left[\mathrm{Bi}(\mathrm{MP})_{3}\left(\mathrm{NO}_{3}\right)_{2} \mathrm{NO}_{3}\right.$

FL1-H
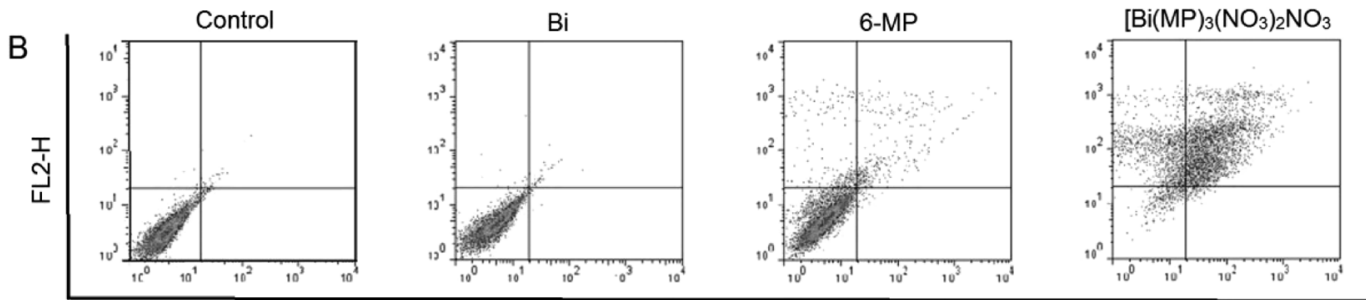

FL1-H
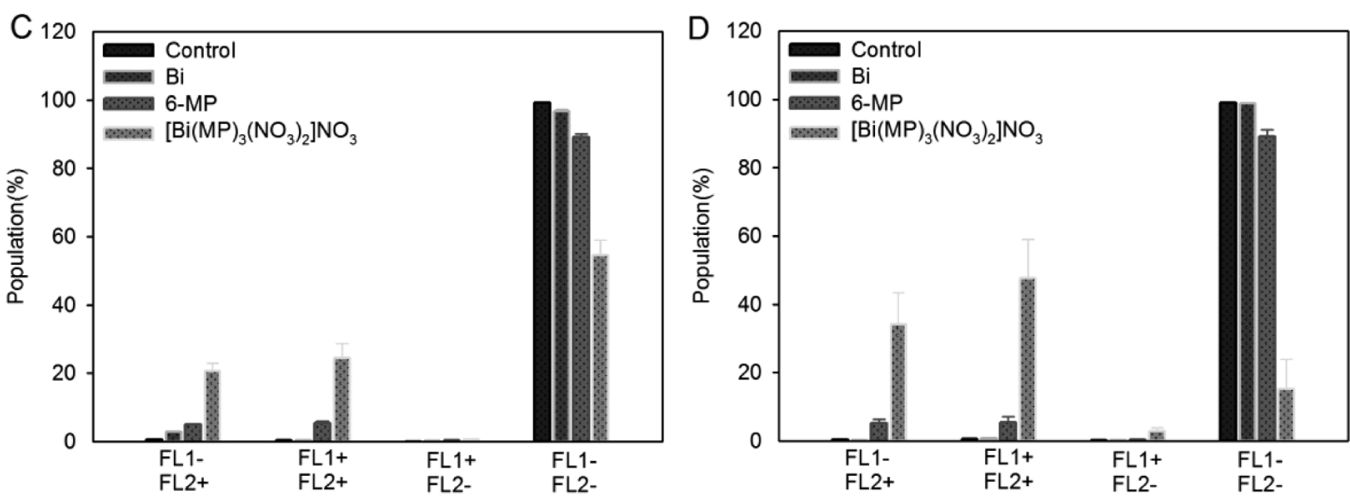

Fig. 8. Flowcytometry Dot Plots of A) A 549 and B) $\mathrm{H} 460$ : Untreated Cells (Control), Cells Treated with $\mathrm{Bi}\left(\mathrm{NO}_{3}\right)_{3}, 6-\mathrm{MP}$ and $\left[\mathrm{Bi}(\mathrm{MP})_{3}\left(\mathrm{NO}_{3}\right)_{2}\right] \mathrm{NO}_{3}$; The Populations of C) A549 and D) H460 Exposed to Different Complexes with the Same Concentration

In all cases, the cells were exposed to the drug for $24 \mathrm{~h}$ at $37^{\circ} \mathrm{C}$. FL1: the green channel of Annexin-V-FITC; FL2: the red channel of PI.

and would likely weaken in vivo tumor migration. More free $\left[\mathrm{Bi}(\mathrm{MP})_{3}\left(\mathrm{NO}_{3}\right)_{2}\right] \mathrm{NO}_{3}$ molecules were available to get into cancer cells due to the improved solubility and thus greatly decreased the activity of cancer cells, leading to the rare migration of A549 or H460 cancer cells to scratch area after a given period treatment.

Apoptosis pathways are frequently found in malignant cells, which arise from the complex interplay of genetic aberrations and misregulated death pathways. $^{22)}$ As discussed above, $\left[\mathrm{Bi}(\mathrm{MP})_{3}\left(\mathrm{NO}_{3}\right)_{2}\right] \mathrm{NO}_{3}$ was proved to be able to kill A549 and H460 cells predominantly through the induction of apoptosis. As shown in Figs. 8A and B, the results of the Annexin-V-fluorescein isothiocyanate/propidium iodide (FITC/PI) double staining for both A549 and H460 indicate that $\left[\mathrm{Bi}(\mathrm{MP})_{3}\left(\mathrm{NO}_{3}\right)_{2}\right] \mathrm{NO}_{3}$ dramatically triggered cellular apoptosis, compared with that from either control or experiment groups treated with $\mathrm{Bi}\left(\mathrm{NO}_{3}\right)_{3}$ and 6-MP. Similarly, once the lung cancer cells A549 and $\mathrm{H} 460$ were incubated with $\left[\mathrm{Bi}(\mathrm{MP})_{3}\left(\mathrm{NO}_{3}\right)_{2}\right] \mathrm{NO}_{3}$ followed by Hoechst staining (Fig. 9), the majority of the cells obviously condensed and displayed highly-fluorescent nuclei, a characteristic morphology of cells undergoing apoptosis, and $\left[\mathrm{Bi}(\mathrm{MP})_{3}\left(\mathrm{NO}_{3}\right)_{2}\right] \mathrm{NO}_{3}$ induced cell apoptosis by $24.95 \pm 4.35 \%$ for A549 and $50.06 \pm 12.05 \%$ for H460 (Figs. 8C, D), respectively, which was much higher than that in either control or $\mathrm{Bi}\left(\mathrm{NO}_{3}\right)_{3}$ treated group (lower than $1.00 \%$ ). In addtion, although 6-MP would induce cell cycle arrest and apoptosis, ${ }^{23,24)}$ only an apoptosis population of $5.00 \%$ was observed for both A549 and $\mathrm{H} 460$ cells after being treated with 6-MP. These results suggested that $\left[\mathrm{Bi}(\mathrm{MP})_{3}\left(\mathrm{NO}_{3}\right)_{2}\right] \mathrm{NO}_{3}$ considerably induced apoptotic cell death of A549 and $\mathrm{H} 460$ cells. Such remakable apoptosis rate in $\left[\mathrm{Bi}(\mathrm{MP})_{3}\left(\mathrm{NO}_{3}\right)_{2}\right] \mathrm{NO}_{3}$ group might benefit from its improved solubility and increased toxicity of $\mathrm{Bi}(\mathrm{III})$ owing to the coordination with 6-MP.

\section{Conclusion}

The combinaiton of $\mathrm{Bi}(\mathrm{III})$ with 6-MP was performed by the reaction of an API without oxygen atoms, 6-MP, with a $\mathrm{Bi}$ (III) salt, $\mathrm{Bi}\left(\mathrm{NO}_{3}\right)_{3} \cdot 5 \mathrm{H}_{2} \mathrm{O}$, leading to the formation of amorphous $\left[\mathrm{Bi}(\mathrm{MP})_{3}\left(\mathrm{NO}_{3}\right)_{2}\right] \mathrm{NO}_{3}$ with excellent anticancer activity. Also, the solubility of $\left[\mathrm{Bi}(\mathrm{MP})_{3}\left(\mathrm{NO}_{3}\right)_{2}\right] \mathrm{NO}_{3}$ was much better than that of 6-MP because of the coordination between $\mathrm{Bi}$ (III) and 6-MP, which was considered to be favorable for efficacious cancer treatment. Rare report currently records that, an important clinical anticancer drug, shows obviously desirable curative effect on human lung cancer cells. However, 6-MP combining with $\mathrm{Bi}(\mathrm{III})$ displayed much lower micromolar $\mathrm{IC}_{50}$ values in the inhibition of cell viability against the A549 and H460 lung cancer cell lines. Moreover, the solubility of 6-MP 


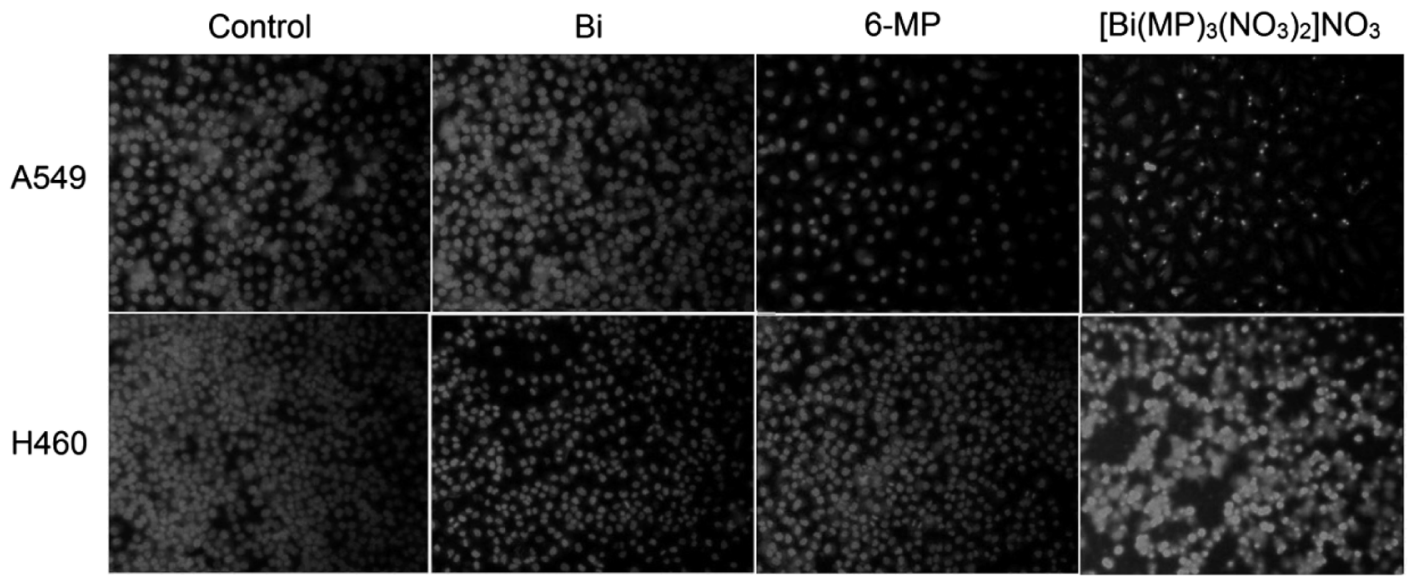

Fig. 9. Hoechst Staining Assay of 549 and H460: Untreated Cells (Control), Cells Treated with $\mathrm{Bi}\left(\mathrm{NO}_{3}\right)_{3}, 6-\mathrm{MP}$ and $\left[\mathrm{Bi}(\mathrm{MP})_{3}\left(\mathrm{NO}_{3}\right)_{2}\right] \mathrm{NO}_{3}$

was increased after being converted to amorphous complex of $\left[\mathrm{Bi}(\mathrm{MP})_{3}\left(\mathrm{NO}_{3}\right)_{2}\right] \mathrm{NO}_{3}$, revealing that such new metal-organic amorphous material provides an alternative viable solid form to improve the solubility of APIs hard to be aqueously disolved.

\section{Experimental}

General Bismuth nitratepentahydrate $\left(\mathrm{Bi}\left(\mathrm{NO}_{3}\right)_{3} \cdot 5 \mathrm{H}_{2} \mathrm{O}\right)$, 6-MP, diethyl ether and ethanol were purchased from Aladdin Reagent Databas Inc. (Shanghai, China) and used as received. All reagents are of analytical grade and used without further purification. All aqueous solutions were prepared with ultrapure water $(>18 \mathrm{M} \Omega)$. EDS was performed with a TESCAN VEGA 3SBH scanning electron microscopy. ${ }^{1} \mathrm{H}-$ and ${ }^{13} \mathrm{C}-\mathrm{NMR}$ spectrum was recorded using an ARX 400 nuclear magnetic resonance spectrometer (Bruker, Germany). FT-IR spectra were obtained with a Spectrophotometer Spectrum 2000. MALDI-TOF-MS data was achieved with AB Sciex 5800 MALDI-TOF/TOF ${ }^{\mathrm{TM}}$ System (U.S.A.). STAs were performed using a TA instrument SDT Q600, an-alumina crucible and synthetic air flow.

$\left[\mathrm{Bi}(\mathrm{MP})_{3}\left(\mathrm{NO}_{3}\right)_{2}\right] \mathbf{N O}_{3} \mathrm{~A} \mathrm{Bi}\left(\mathrm{NO}_{3}\right)_{3}$ solution was first prepared by dissolving $0.485 \mathrm{~g} \mathrm{Bi}\left(\mathrm{NO}_{3}\right)_{3} \cdot 5 \mathrm{H}_{2} \mathrm{O}$ solid $(1 \mathrm{mmol})$ in ethanol with the help of a few drops of nitric acid and then added dropwise into $100 \mathrm{~mL}$ ethanol solution containing $0.456 \mathrm{~g}$ 6-MP $(3 \mathrm{mmol})$. After being refluxed for $1 \mathrm{~h}$ at $85^{\circ} \mathrm{C}$ under stirring, the resulting solution formed a yellow precipitate. The obtained crude product was then thoroughly washed with acetone and dried in vacuo. $\left[\mathrm{Bi}(\mathrm{MP})_{3}\left(\mathrm{NO}_{3}\right)_{2}\right] \mathrm{NO}_{3}$ $\left(\mathrm{C}_{15} \mathrm{H}_{12} \mathrm{BiN}_{15} \mathrm{O}_{9} \mathrm{~S}_{3}, \mathrm{MW}=851.53\right)$ ): yellow solid, FT-IR (thin film, neat) $v_{\max } 1611, \quad 1388, \quad 1213,871 \mathrm{~cm}^{-1} ;{ }^{1} \mathrm{H}-\mathrm{NMR}$ (400 MHz, DMSO) $\delta: 13.81$ (s, 1H, -C-NH-), 8.43 (s, 1H, $\left.{ }_{-} \mathrm{CH}=\mathrm{N}-\right), 8.25(\mathrm{~s}, 1 \mathrm{H},-\mathrm{CH}=\mathrm{N}-), 3.64(\mathrm{~m}, 1 \mathrm{H},-\mathrm{C}-\mathrm{NH}-)$. ${ }^{13} \mathrm{C}-\mathrm{NMR}$ (151 MHz, DMSO) $\delta: 170.54$ (C6), 150.24 (C4), 144.86 (C2), 144.67 (C8), 129.17 (C5). Anal. (\%) Calcd: C, 21.16; H, 1.42; Bi, 24.54; N, 24.67; O, 16.91; S, 11.30. MALDITOF-MS (m/z): $790.04[\mathrm{M}]^{+}$.

Cell Culture Human lung cancer cell lines A549 and H460 were maintained in Dulbecco's modified Eagle's medium (DMEM) (high glucose) (GIBCO, Invitrogen, U.S.A.) and supplemented with $10 \%$ fetal bovine serum (GIBCO), 100 units $/ \mathrm{mL}$ penicillin and $100 \mathrm{mg} / \mathrm{mL}$ streptomycin in a humidified incubator under $5 \% \mathrm{CO}_{2}$ at $37^{\circ} \mathrm{C}$.
Cytotoxicity Assay The 3-(4,5-dimethylthiazol-2-yl)-2,5diphenyltetrazolium bromide (MTT) assay was carried out to evaluate the cytotoxicity. A549 and H460 cells were placed in 96-well plates at a density of $1 \times 10^{4}$ cells/well and then incubated with the tested compounds. After $24 \mathrm{~h}$ incubation, cultures were incubated in $100 \mu \mathrm{L}$ of the medium containing $10 \mu \mathrm{L} 5 \mathrm{mg} / \mathrm{mL}$ MTT solution for $4 \mathrm{~h}$ at $37^{\circ} \mathrm{C}$. Afterwards, the medium with MTT was removed, and $100 \mu \mathrm{L}$ of DMSO was added to each well so as to dissolve the formazan. The absorbance at $570 \mathrm{~nm}$ was measured with a microplate reader (Bio-Tek ELX800, U.S.A.). The inhibitory percentage of each compound at various concentrations was calculated so as to determine the $\mathrm{IC}_{50}$ value.

In Vitro Inhibition Rate of $\left[\mathrm{Bi}(\mathrm{MP})_{3}\left(\mathrm{NO}_{3}\right)_{2}\right] \mathrm{NO}_{3} \mathrm{~A} 549$ and $\mathrm{H} 460$ cells were seeded in a 96-well plate at a density of $0.5 \times 10^{4}$ cells/well at $37^{\circ} \mathrm{C}$ in $5 \% \mathrm{CO}_{2}$. The cells were then incubated in a complete medium containing $\left[\mathrm{Bi}(\mathrm{MP})_{3}\left(\mathrm{NO}_{3}\right)_{2}\right] \mathrm{NO}_{3}$ with 5 different concentrations $(0,5$, $10,20,40 \mu \mathrm{m})$ according to $\mathrm{IC}_{50}$, respectively. MTT assay was conducted to evaluate the cell viabilities in each group through $0,12,24,48$ and $72 \mathrm{~h}$ of incubations.

In Vitro Colony Formation Assay A549 and H460 cells were seeded in a 6 -well plate at a density of 400 cells/well at $37^{\circ} \mathrm{C}$ in $5 \% \mathrm{CO}_{2}$. The cells were then incubated in a complete medium containing $1 \%$ DMSO and $10 \mu \mathrm{M}$ of $\mathrm{Bi}\left(\mathrm{NO}_{3}\right)_{3}$ (shown as $\mathrm{Bi}$ in all figures below), 6-MP and $\left[\mathrm{Bi}(\mathrm{MP})_{3}\left(\mathrm{NO}_{3}\right)_{2}\right] \mathrm{NO}_{3}$. The colony was counted only if it contained more than 50 cells, and the number of colonies was counted on the 7th day after seeding. Colony formation rate was calculated with the equation below:

$$
\text { Colony formation rate }=\frac{\text { number of colonies }}{\text { number of seeded cells }} \times 100 \%
$$

Each treatment was carried out in quintuplicate.

In Vitro Cell Migration Assay A549 and $\mathrm{H} 460$ cells were seeded in a 6-well plate at a density of $3 \times 10^{5}$ cells/well at $37^{\circ} \mathrm{C}$ in $5 \% \mathrm{CO}_{2}$. After cells formed a cell monolayer, the scratch line was made through the cell monolayer vertically with a $200 \mu \mathrm{L}$ tip. The culture medium was then sucked out with a pipette and the floating cells left was removed by washing with phosphate buffered saline (PBS) for three times. The cultured cells were incubated in $1 \%$ fetal bovine serum medium containing $1 \% \mathrm{DMSO}$, and $\mathrm{Bi}\left(\mathrm{NO}_{3}\right)_{3}, 6-\mathrm{MP}$ as well 
as $\left[\mathrm{Bi}(\mathrm{MP})_{3}\left(\mathrm{NO}_{3}\right)_{2}\right] \mathrm{NO}_{3}$ with an equivalent concentration of $10 \mu \mathrm{M}$ at $37^{\circ} \mathrm{C}$ in $5 \% \mathrm{CO}_{2}$, respectively. The cell migration was captured at the time of $0,6,12$ and $24 \mathrm{~h}$ with the corresponding cell-uncovered line width recorded. The cell migration rate was calculated according to the below equation:

$$
\text { cell migration rate }=\left(S_{\mathrm{c}} / S_{\mathrm{a}}\right) \times 100 \%
$$

where $S_{\mathrm{a}}$ is the migration width for control group and $S_{\mathrm{c}}$ the migration width for the analysis group.

Cellular Apoptosis Evaluation Cell apoptosis was evaluated with an Annexin V-FITC/PI apoptosis detection kit on a BD FACSCalibur Flow Cytometry (U.S.A.) and a Hochest33258 kit on a Nikon TE2000-U Inverted Fluorescence Microscope. Briefly, the A549 and H460 cells were seeded in 12-well plates and treated in a complete medium containing $1 \% \mathrm{DMSO}$ and $10 \mu \mathrm{M}$ of $\mathrm{Bi}\left(\mathrm{NO}_{3}\right)_{3}, 6-\mathrm{MP}$ or $\left[\mathrm{Bi}(\mathrm{MP})_{3}\left(\mathrm{NO}_{3}\right)_{2}\right] \mathrm{NO}_{3}$ for $24 \mathrm{~h}$, followed by the harvesting and staining according to the manufacturer's protocol. The resulting images were finally collected and data were analyzed on Flowjo 7.6 software (Treestar, Ashland, OR, U.S.A.).

Statistical Analysis Experimental data were compared using the Student's $t$-test. Results obtained were expressed as the mean \pm standard deviation (S.D.) and considered to be statistically significant when $* p<0.05, * * p<0.01$ or $* * * p<0.001$.

Acknowledgments This work was supported by the National Natural Science Foundation of China (21305090, 21401130), the Shanghai Natural Science Foundation (13ZR1428300), the Innovation Program of Shanghai Municipal Education Commission (14YZ086, 14ZZ139), the State Key Laboratory of Analytical Chemistry for Life Science (SKLACLS1502) and the Fundamental Research Funds for the Central Universities (to Shuang Zhou). The authors greatly appreciated these supports.

Conflict of Interest The authors declare no conflict of interest.

Supplementary Materials The online version of this article contains supplementary materials.

\section{References}

1) Kola I., Landis J., Nat. Rev. Drug Discov., 3, 711-716 (2004).

2) Yu L., Adv. Drug Deliv. Rev., 48, 27-42 (2001).

3) Wang C. C., Chiou S. S., Wu S. M., Electrophoresis, 26, 2637-2642 (2005).

4) Kato Y., Matsushita T., Yokoyama T., Mohri K., Pharm. Res., 9 , 697-699 (1992)

5) Zacchigna M., Cateni F., Di Luca G., Drioli S., Bioorg. Med. Chem. Lett., 17, 6607-6609 (2007).

6) Krüger K., Die romanischen Westbauten in Burgund und Cluny: Untersuchungen zur Funktion einer Bauform, Gebr. Mann Verlag, Berlin, 2003.

7) Briand G. G., Burford N., Chem. Rev., 99, 2601-2658 (1999).

8) Tiekink E. R. T., Crit. Rev. Oncol. Hematol., 42, 217-224 (2002).

9) Li W., Jin L., Zhu N. Y., Hou X. M., Deng F., Sun H. Z., J. Am. Chem. Soc., 125, 12408-12409 (2003).

10) Andrews P. C., Deacon G. B., Forsyth C. M., Junk P. C., Kumar I., Maguire M., Angew. Chem. Int. Ed., 45, 5638-5642 (2006).

11) Shen S., Li X. F., Cullen W. R., Weinfeld M., Le X. C., Chem. Rev., 113, 7769-7792 (2013).

12) Sapra A., Thorpe C., J. Am. Chem. Soc., 135, 2415-2418 (2013).

13) Park D., Don A. S., Massamiri T., Karwa A., Warner B. MacDonald J., Hemenway C., Naik A., Kuan K. T., Dilda P. J., Wong J. W. H., Camphausen K., Chinen L., Dyszlewski M., Hogg P. J., J. Am. Chem. Soc., 133, 2832-2835 (2011).

14) Huang C. S., Yin Q., Zhu W. P., Yang Y., Wang X., Qian X. H., Xu Y. F., Angew. Chem. Int. Ed., 50, 7551-7556 (2011).

15) Griffin B. A., Adams S. R., Tsien R. Y., Science, 281, 269-272 (1998).

16) Silvestru C., Breunig H. J., Althaus H., Chem. Rev., 99, 3277-3328 (1999).

17) Mohan R., Nat. Chem., 2, 336 (2010).

18) Salvador J. A. R., Figueiredo S. A. C., Pinto R. M. A., Silvestre S. M. Future, Med. Chem., 4, 1495-1523 (2012).

19) Li H., Sun H. Z., Curr. Opin. Chem. Biol., 16, 74-83 (2012).

20) Yao J., Chen J. M., Xu Y. B., Lu T. B., Cryst. Growth Des., 14, 5019-5025 (2014).

21) Cuin A., Massabni A. C., Pereira G. A., Leite C. Q. F., Pavan F. R., Sesti-Costa R., Heinrich T. A., Costa-Neto C. M., Biomed. Pharmacother., 65, 334-338 (2011).

22) Hanahan D., Weinberg R. A., Cell, 144, 646-674 (2011).

23) Kanemitsu H., Yamauchi H., Komatsu M., Yamamoto S., Okazaki S., Uchida K., Nakayama H., Neurotoxicol. Teratol., 31, 104-109 (2009).

24) Kanemitsu H., Yamauchi H., Komatsu M., Yamamoto S., Okazaki S., Uchida K., Nakayama H., Neurotoxicol. Teratol., 31, 198-202 (2009). 